\title{
Proteomics and molecular medicine
}

\author{
Margaret Simonian* \\ David Geffen School of Medicine, University of California Los Angeles (UCLA), USA
}

\section{Editorial topic}

Molecular Medicine promotes the understanding of biological mechanism of disease at the cellular and molecular levels for better diagnoses, treatment, and prevention of disease. Proteomics plays an important role in medical research and molecular medicine, such as in drug discovery and diagnostics, because of the link between proteins, genes and diseases, and it is considered to be the next step in modern biology [1]. Understanding protein functions help to understand diseases, most current drugs are either proteins or targeting specific proteins in the body [2]. Identifying unique protein expression associated with specific diseases is a very important and promising area in the field of clinical proteomics. Neuroproteomics is a rising application in the study of brain disorders. Proteomics analysis of brain tissue is an essential part of neuroscience research [3-5], although it faces many challenges, most importantly the difficulty of obtaining sufficient sample for mass spectrometry analysis (MS), which requires at least 30 nanograms of protein. Usually $30-40 \%$ of proteins are lost during the sample preparation process, therefore low abundance proteins will not always be detected by (MS) [6,7]. The availability of animal models may solve these problems in some cases.

Proteomics is dynamic compared to genomics because it changes constantly to reflect the cell's environment. The main objectives in the field of proteomics are; identifying all proteins, analyse differential protein expression in different samples, characterise proteins by identifying and studying their function and cellular localisation, and understand protein interaction networks.

Proteomics relies on; successful protein separation and purification techniques, mass spectrometry analysis, bioinformatics, and gene and protein databases. Sample preparation is the most critical and challenging task in any successful proteomics project [8]. Isolation of proteins involves releasing proteins by breaking the cell wall and solubilising the proteins in a buffer for fractionation and analysis [9]. Isolation methods can vary from simple solubilisations to more complex extractions based on the tissue and cell types. The difficulties involving in the purification methods and recovery of protein are the major obstacles to characterization assays, especially of low abundance proteins such as membrane proteins [10].

Quantitative labelled and label free proteomics technologies contributes to studies aimed at revealing disease pathways, biomarker discovery and drug development [7]. The continuous advancement in these technologies promises the fast and better analysis of proteins, understanding their function and role in many important diseases such as Alzheimer's, Parkinson's and cancers.

\section{References}

1. Simonian M (2015) Cerebral Arteriovenous Malformations (AVMs): Causes, Treatment and Research. MOJ proteomics and Bioinformatics 2: 5 .

2. Wulfkuhle JD, Liotta A, Petricoin EF (2003) Early detection: Proteomic applications for the early detection of cancer. Nat Rev Cancer 3: 267-75. [Crossref]

3. Simonian M, Molloy MP, Stoodley MA (2012) In vitro and in vivo biotinylation of endothelial cell surface proteins in the pursuit of targets for vascular therapies for brain AVMs. Metabol $J$.

4. Simonian M, Loo RRO, Loo JA, Stoodley MA, Molloy MP (2014) Proteomics Detection of Endothelial Cell Surface Proteins Following Irradiation as Potential Targets for Brain Arteriovenous Malformations Molecular Therapy. MOJ Prot Bioinf.

5. Barkhoudarian G, Whitelegge JP, Kelly DF, Simonian M (2016) Proteomics analysis of brain meningiomas in pursuit of novel biomarkers of the aggressive behavior. $J$ Proteo Bioinfo 9: 53-57. [Crossref]

6. Ball H, Roulhac L. Alzate O. (2010) Multidimensional Techniques in Protein Separations for Neuroproteomics. Neuroproteomics. Boca Raton (FL) Chapter 3. [Crossref]

7. Butcher J (2007) Neuroproteomics comes of age. Lancet Neurol. 6: 850

8. Hall J, Morton I (1999) Concise dictionary of pharmacological agents: properties and synonyms. Kluwer Academic 255: 5521-4.

9. Bodzon-Kulakowska A, Bierczynska-Krzysik A, Dylag T (2007) Methods for samples preparation in proteomic research. Journal of Chromatography B-Analytical Technologies in the Biomedical and Life Sciences. 849: 1-31. [Crossref]

10. Cañas B, Piñeiro C, Calvo E, López-Ferrer D, Gallardo JM (2007) Trends in sample preparation for classical and second generation proteomics. J Chromatogr A 153: 23558. [Crossref]
Copyright: (C2016 Simonian M. This is an open-access article distributed under the terms of the Creative Commons Attribution License, which permits unrestricted use, distribution, and reproduction in any medium, provided the original author and source are credited.
Correspondence to: Margaret Simonian, David Geffen School of Medicine, University of California Los Angeles (UCLA), 611 Charles E. Young Drive East, CA. 90095, USA, Tel: +(1) 310-794-7308; Mobile +(1) 310-893-4593; E-mail: margaret@chem.ucla.edu

Received: July 27, 2016; Accepted: August 05, 2016; Published: August 09, 2016 